UDK $577.1: 61$

ISSN 1452-8258

J Med Biochem 39: 384-391, 2020

\title{
GENDER- AND AGE-SPECIFIC REFERENCE INTERVALS OF COMMON BIOCHEMICAL ANALYTES IN CHINESE POPULATION - DERIVATION USING REAL LABORATORY DATA
}

\author{
POLNI I STAROSNI REFERENTNI INTERVALI UOBIČAJENIH BIOHEMIJSKIH ANALITA \\ U KINESKOJ POPULACIJI - IZVOĐENJE KORIŠĆENJEM STVARNIH \\ LABORATORIJSKIH PODATAKA
}

\author{
Danchen Wang ${ }^{1}$, Chaochao Ma1, Yutong Zou1, Songlin Yu' ${ }^{1}$, Honglei Li1, \\ Xinqi Cheng ${ }^{1}$, Ling Qiu ${ }^{1}$, Tengda Xu ${ }^{2}$ \\ ${ }^{1}$ Department of Clinical Laboratory, Peking Union Medical College Hospital, \\ Peking Union Medical College \& Chinese Academy of Medical Science, Beijing, China \\ ${ }^{2}$ Department of Health Care, Peking Union Medical College Hospital, Chinese Academy of Medical Sciences, \\ No.1 Shuaifu Yuan, Dongcheng District, Beijing, China
}

\begin{abstract}
Summary
Background: Indirect sampling methods are not only inexpensive but also efficient for establishing reference intervals (RIs) using clinical data. This study was conducted to select fully normal records to establish age- and genderspecific Rls for common biochemical analytes by laboratory data mining.

Methods: In total, 280,206 records from 2014 to 2018 were obtained from Peking Union Medical College Hospital. Common biochemical analytes [total protein, albumin, total bilirubin (TBil), direct bilirubin (DBil), alanine aminotransferase (ALT), glutamyltranspeptidase (GGT), alkaline phosphatase (ALP), aspartate aminotransferase (AST), lactate dehydrogenase $(\mathrm{LDH})$, potassium, sodium, chlorine, calcium, urea, glucose, uric acid (UA), inorganic phosphorus, creatinine $(\mathrm{Cr})$, total cholesterol, triglyceride, high-density lipoprotein cholesterol, and low-density lipoprotein cholesterol] were measured using an automatic analyzer. Sources of variation were identified by multiple regression analysis. The $2.5^{\text {th }}$ and $97.5^{\text {th }}$ percentiles were calculated as the lower and upper limits of the RIs, respectively.
\end{abstract}

\footnotetext{
Address for correspondence:

Professor Ling Qiu

Department of Clinical Laboratory, Peking Union Medical College Hospital, Chinese Academy of Medical Sciences, No. 1 Shuaifu Yuan, Dongcheng District, Beijing 100730, China e-mail: lingqiubj@163.com

Professor Tengda Xu

Department of Health Care, Peking Union Medical College Hospital, Chinese Academy of Medical Sciences, No. 1 Shuaifu Yuan, Dongcheng District, Beijing 100730, China e-mail: Xutd@pumch.cn
}

\begin{abstract}
Kratak sadržaj
Uvod: Metode indirektnog uzorkovanja nisu samo jeftine, već su i efikasne za uspostavljanje referentnih intervala (RI) korišćenjem velike količine kliničkih podataka. Ova studija je sprovedena sa ciljem da se odaberu potpuno normalni pojedinačni zapisi da bi se utvrdio RI za starost i pol za zajedničke biohemijske analite pomoću laboratorijski dobijenih podataka.

Metode: Ukupno je uzeto 280.206 pojedinačnih rezultata u periodu od 2014. do 2018. godine iz bolnice Peking Union Medical College-a. Uobičajeni biohemijski analiti [ukupni protein, albumin, ukupni bilirubin (TBil), direktni bilirubin (DBil), alanin aminotransferaza (ALT), glutamiltranspeptidaza (GGT), alkalna fosfataza (ALP), aspartat aminotransferaza (AST), laktat dehidrogenaza (LAT) kalijum, natrijum, hlor, kalcijum, ureja, glukoza, mokraćna kiselina (UA), neorganski fosfor, kreatinin (Cr), ukupni holesterol, trigliceridi, lipoprotein holesterola visoke gustine i lipoprotein holesterola niske gustine] mereni su korišćenjem automatskog analizatora. Izvori varijacije identifikovani su višestrukom regresionom analizom. Postoci $(2,5$ i 97,5$)$ su izračunati kao donja i gornja granica RI, svaki ponaosob.
\end{abstract}

List of abbreviations: TP, total protein; Alb, albumin; TBil, total bilirubin; DBil, direct bilirubin; ALT, alanine aminotransferase; GGT, glutamyl transferase; ALP, alkaline phosphatase; AST, aspartate aminotransferase; LDH, lactate dehydrogenase; K, potassium; $\mathrm{Na}$, sodium; $\mathrm{Cl}$, chlorine; $\mathrm{Ca}$, calcium; $\mathrm{Glu}$, glucose; UA, uric acid; IP, inorganic phosphorus; $\mathrm{Cr}$, creatinine; TC, total cholesterol; TG, triglyceride; HDL-C, high-density lipoprotein cholesterol; LDL-C, low-density lipoprotein cholesterol; SVs, source of variation. 
Results: Gender was the major source of variation among the 13 common biochemical analytes with an $r_{p}>0.15$. In contrast to the value listed in the WS/T 404, nearly all RIs established in this study were significantly narrower. Furthermore, age-specific Rls should be determined for DBil, LDH, and urea, whereas gender-specific Rls are suggested for GGT, LDH, and urea.

Conclusions: We recommend that gender-specific RIs should be established for ALT, AST, GGT, DBil, TBil, UA, and $\mathrm{Cr}$ as well as gender- and age-specific RIs for urea and ALP. Through indirect sampling, age- and gender-specific Rls for common biochemical analytes were established and analyzed.

Keywords: reference interval, large data set, Chinese population, indirect sampling method

\section{Introduction}

As parameters routinely used for clinical interpretation, reference intervals were first described in 1969 (1) and defined as prediction intervals that include the central $95 \%$ of reference values (2). It is necessary to establish Rls for common analytes at large three-level general hospitals because the concentration of a given analyte may be affected by various factors such as gender, age, and ethnicity, among others (3). Numerous studies have reported common Rls based on traceable results that can be used for analytes with good traceability from different manufacturers to the same higher-order references (4-6). Reliable Rls are determined in completely healthy individuals but show variations (7-10). It is critical but difficult for each clinical laboratory to establish Rls (11), as it is not easy to recruit healthy individuals and ensure pre-analysis, mid-analysis, and post-analysis quality control. According to Clinical \& Laboratory Standards Institute (CLSI) C28-A3 guidelines, two methods should be used to establish Rls: direct and indirect sampling methods $(3,12)$. Establishing RIs by recruiting healthy individuals is a direct sampling method, which is costly and time-consuming $(10,13$, 14). First described in 1963 (15), indirect sampling must include a large number of normal individual records from databases, which is based on data mining techniques, cost-effective, and easier to perform in less time with lower material resources $(7,16)$ compared to direct sampling methods.

Accordingly, the aim of this study was to enroll completely normal records, establish age- and gender-specific Rls for common biochemical analytes, and compare the Rls with those listed in WS/T 404 (18-24).

\section{Materials and Methods}

\section{Source data}

In total, 280,206 records from 2014 to 2018 were obtained from the Peking Union Medical College Hospital. Each record included height,
Rezultati: Pol je bio glavni izvor varijacije među 13 uobičajenih biohemijskih analita sa $r_{p}>0,15$. Za razliku od vrednosti navedene u WS / T 404, skoro svi RI utvrđeni u ovoj studiji bili su znatno uži. Dalje, za DBil, LDH i ureju trebalo bi odrediti Rl specifične za starost, dok su za GGT, LDH i ureu, starosni referentni intervali predloženi.

Zaključak: Preporučujemo da se utvrde referentni intervali specifični za pol za ALT, AST, GGT, DBil, TBil, UA i Cr, kao i referentni intervali specifični za pol i starost za ureju i ALP. Kroz indirektno uzorkovanje utvrđeni su $i$ analizirani referentni intervali specifični za starosnu dob i za zajedničke biohemijske analite.

Ključne reči: referentni interval, veliki skup podataka, kineska populacija, metoda indirektnog uzorkovanja

weight, systolic blood pressure (SBP), diastolic blood pressure (DBP), heart rate, nutrition status, past disease history, current symptoms, heart rhythm, abdominal palpation results, and basic biochemical measurements results. Basic laboratory measurements were collected including total protein (TP), albumin (Alb), total bilirubin (TBil), direct bilirubin (DBil), alanine aminotransferase (ALT), glutamyltranspeptidase (GGT), alkaline phosphatase (ALT), aspartate aminotransferase (AST), lactate dehydrogenase $(\mathrm{LDH})$, potassium $(\mathrm{K})$, sodium $(\mathrm{Na})$, chlorine $(\mathrm{Cl})$, calcium (Ca), urea, glucose (Glu), uric acid (UA), inorganic phosphorus (IP), creatinine $(\mathrm{Cr})$, total cholesterol (TC), triglyceride (TG), high-density lipoprotein cholesterol (HDL-C), and low-density lipoprotein cholesterol (LDL-C). All common biochemical analytes were measured on a Roche C8000 automatic biochemical analyzer (Basel, Switzerland). Bodyweight was measured on a calibrated beam scale, and body mass index (BMI) was calculated as body weight divided by the square of the height $\left(\mathrm{kg} / \mathrm{m}^{2}\right)$. Blood pressure was measured after the participants had rested quietly for at least $20 \mathrm{~min}$. All testing records associated with internal quality control, external quality assessment, and other interfering factors during this period were reviewed. All results were anonymized before analysis.

\section{Definition of the reference population}

To establish RIs, we first defined "apparently healthy" individuals according to the protocol provided by the IFCC Committee on Reference Intervals and Decision Limits (17). The following participants were excluded: (1) patients with acute or chronic diseases that required medical intervention including respiratory diseases, circulatory system disorders, liver or kidney diseases, acute and chronic infections, metabolic and nutritional disorders, autoimmune diseases, endocrine diseases, hematological diseases, and malignant tumor; 2) patients with $\mathrm{BMI} \geq 28$ or $\leq 18.5 \mathrm{~kg} / \mathrm{m}^{2}$; (3) patients with an SBP of $\geq 160$ $\mathrm{mmHg}$ or DBP of $\geq 100 \mathrm{mmHg}$; and (4) patients with incomplete biochemical tests. 
A total of $148,332(52.9 \%)$ participants were enrolled in this study. This study was approved by the Ethics Committee of Peking Union Medical College Hospital of the Chinese Academy of Medical Sciences. As this study was retrospective in nature and the results were anonymized, informed consent for the use of samples was not required.

\section{Definition of »fully normal individuals« by secondary exclusion}

Secondary exclusion of candidate reference individuals was performed according to the Tukey method to exclude outliers. A previous study revealed that Alb, UA, Glu, HDL-C, LDL-C, TG, AST, ALT, and GGT represented changes in nutrition status and metabolic syndrome (the most prevalent latent disease) (25). Thus, we used the Tukey method to exclude abnormal tests results. A total of 125,509 (44.8\%) individuals considered as fully normal individuals were enrolled in the final analysis.

\section{Statistical analysis}

Data were analyzed using SPSS 20.0 software (SPSS, Inc., Chicago, IL, USA). Multiple regression analysis (MRA) was performed to identify sources of variation (SVs) potentially affecting common biochemical analytes. A standardized partial regression coefficient $\left(r_{p}\right)$ of $>0.15$ was considered practically significant, corresponding to $P<0.0001$ with a large sample size of approximately 1500 . Analysis of variance or the Mann-Whitney $U$ test was performed to evaluate the significance of differences between subgroups, such as gender and age $(26,27)$. Using a nonparametric method, Rls were calculated as the $2.5^{\text {th }}$ percentile confidence interval $\left(P_{2.5}\right)$ and $97.5^{\text {th }}$ percentile confidence interval $\left(P_{97.5}\right)$ according to CLSI C28-A3 (12).

\section{Results}

Basic characteristics of enrolled fully normal individual records

A total of 125,509 fully normal individual records (male: $\mathrm{n}=$ 55.885; female: $\mathrm{n}=69.624$ ) were enrolled in this study (Table I).

\section{SVs of RIs of common biochemical analytes}

MRA was performed to evaluate the SVs of common biochemical analytes. The results are shown in Table II. Gender was the major SV for Alb, TBil, DBil, ALT, GGT, ALP, AST, Na, Ca, urea, UA, Cr, and HDL-C $\left(r_{p}>0.15\right)$. Age was also an important SV for TP, AST, LDH, Na, Cl, Ca, urea, Glu, TC, TG, and LDL-C. BMI was associated with ALT, GGT, TG, HDL$\mathrm{C}$, and LDL-C. However, SBP and DBP showed no significant association with any common biochemical analytes.

Distribution of common biochemical analytes by gender and age

The distribution of common biochemical analytes of fully healthy individuals according to gender are shown in Table III. The median TBil, DBil, ALT, GGT, ALP, AST, LDH, urea, UA, Cr, TG, HDL-C, and LDL-C values in males were significantly higher than those in females. TP, Alb, K, Na, Cl, IP, Ca, Glu, and TC were significantly different between males and females. Common biochemical analyte levels by age are shown in Table IV. The serum levels of GGT, LDH, urea, Glu, Cr, TC, TG, and LDL-C increased with age, whereas HDL-C levels decreased with age. The ALP levels were sharply increased in patients older than 50 years of age.

\section{Rls of common biochemical analytes}

Based on their SVs and distribution, the Rls for common biochemical analytes were calculated. All Rls established in this study were significantly narrower than those given by the WS/T 404 (18-24) (Supplemental Table I). The ranges of TP, ALT, GGT, $A L P, A S T, K, N a, C l$, and IP in this study were significantly lower, whereas the distributions of Alb, TBil, and $\mathrm{Ca}$ were higher than those suggested by the WS/T 404. We recommended establishing genderspecific RIs for ALT, AST, GGT, DBil, TBil, UA, and $\mathrm{Cr}$ and gender- and age-specific RIs for urea and ALP.

Table I Characteristics of fully normal individual records.

\begin{tabular}{|c|c|c|c|c|}
\hline & Male & Female & P-value & Total \\
\hline $\mathrm{N}(\%)$ & $55885(44.5 \%)$ & $69624(55.9 \%)$ & --- & 125509 \\
\hline Age, years & $38.8 \pm 10.9$ & $38.9 \pm 10.6$ & 0.385 & $38.8 \pm 10.7$ \\
\hline $\mathrm{BMl}, \mathrm{kg} / \mathrm{m}^{2}$ & $23.9 \pm 2.2$ & $22.2 \pm 2.3$ & $<0.001$ & $22.9 \pm 2.4$ \\
\hline $\mathrm{SBP}, \mathrm{mmHg}$ & $120 \pm 14$ & $110 \pm 14$ & $<0.001$ & $115 \pm 15$ \\
\hline $\mathrm{DBP}, \mathrm{mmHg}$ & $75 \pm 9$ & $68 \pm 9$ & $<0.001$ & $71 \pm 9$ \\
\hline
\end{tabular}

a: $P$ values between male and female. 
Table II Source of variations in Rls of common biochemical analytes (rp).

\begin{tabular}{|c|c|c|c|c|c|c|}
\hline Analyte & $\mathrm{R}$ & Gender & Age & BMI & SBP & DBP \\
\hline TP, g/L & 0.269 & 0.007 & -0.222 & -0.058 & 0.099 & 0.110 \\
\hline Alb, g/L & 0.366 & -0.385 & -0.051 & -0.044 & -0.017 & -0.018 \\
\hline TBil, $\mu \mathrm{mol} / \mathrm{L}$ & 0.309 & -0.312 & -0.037 & -0.090 & 0.028 & 0.011 \\
\hline DBil, $\mu \mathrm{mol} / \mathrm{L}$ & 0.3 & -0.300 & -0.059 & -0.128 & 0.048 & -0.013 \\
\hline $\mathrm{ALT}, \mathrm{U} / \mathrm{L}$ & 0.472 & -0.313 & 0.023 & 0.216 & 0.019 & 0.042 \\
\hline GGT, U/L & 0.498 & -0.330 & 0.102 & 0.193 & -0.020 & 0.095 \\
\hline ALP, U/L & 0.338 & -0.185 & 0.143 & 0.090 & 0.107 & -0.009 \\
\hline AST, U/L & 0.327 & -0.216 & 0.180 & 0.043 & 0.056 & -0.002 \\
\hline $\mathrm{LDH}, \mathrm{U} / \mathrm{L}$ & 0.314 & -0.059 & 0.173 & 0.099 & 0.148 & -0.010 \\
\hline $\mathrm{K}, \mathrm{mmol} / \mathrm{L}$ & 0.063 & 0.017 & 0.021 & 0.057 & 0.019 & -0.028 \\
\hline $\mathrm{Na}, \mathrm{mmol} / \mathrm{L}$ & 0.349 & -0.276 & 0.182 & 0.008 & 0.061 & -0.029 \\
\hline $\mathrm{Cl}, \mathrm{mmol} / \mathrm{L}$ & 0.233 & 0.110 & 0.161 & 0.077 & -0.069 & -0.058 \\
\hline $\mathrm{Ca}, \mathrm{mmol} / \mathrm{L}$ & 0.283 & -0.172 & -0.159 & -0.050 & 0.109 & 0.039 \\
\hline Urea, $\mathrm{mol} / \mathrm{L}$ & 0.36 & -0.308 & 0.192 & 0.018 & 0.020 & -0.048 \\
\hline Glu, mmol/L & 0.366 & -0.060 & 0.216 & 0.120 & 0.116 & 0.040 \\
\hline UA, $\mu \mathrm{mol} / \mathrm{L}$ & 0.668 & -0.557 & -0.085 & 0.181 & 0.033 & 0.020 \\
\hline IP, mmol/L & 0.31 & 0.220 & -0.126 & -0.075 & -0.001 & -0.036 \\
\hline $\mathrm{Cr}, \mu \mathrm{mol} / \mathrm{L}$ & 0.771 & -0.767 & 0.019 & 0.012 & 0.010 & -0.011 \\
\hline $\mathrm{TC}, \mathrm{mmol} / \mathrm{L}$ & 0.311 & 0.050 & 0.267 & 0.066 & 0.020 & 0.066 \\
\hline TG, mmol/L & 0.451 & -0.134 & 0.172 & 0.257 & -0.018 & 0.128 \\
\hline $\mathrm{HDL}-\mathrm{C}, \mathrm{mmol} / \mathrm{L}$ & 0.485 & 0.294 & 0.045 & -0.295 & 0.033 & -0.038 \\
\hline LDL-C, mmol/L & 0.363 & -0.059 & 0.249 & 0.151 & 0.007 & 0.069 \\
\hline
\end{tabular}

$\mathrm{R}$ represents the multiple correlation coefficient. Values shown are standardized partial regression coefficients (rp). Values of (rp) $\geq 0.15$ that were significant are marked in bold letters.

Table III Distribution of common biochemical analytes by gender.

\begin{tabular}{|l|c|c|c|c|c|c|c|c|c|}
\hline Analyte & \multicolumn{3}{|c|}{ Total } & \multicolumn{3}{c|}{ Male } & \multicolumn{3}{c|}{ Female } \\
\hline & Median & $\mathrm{LL}$ & $\mathrm{UL}$ & Median & $\mathrm{LL}$ & $\mathrm{UL}$ & Median & $\mathrm{LL}$ & $\mathrm{UL}$ \\
\hline $\mathrm{TP}, \mathrm{g} / \mathrm{L}$ & 73 & 66 & 80 & 73 & 66 & 80 & 73 & 66 & 80 \\
\hline $\mathrm{TBil}, \mu \mathrm{mol} / \mathrm{L}$ & 11 & 5 & 26 & 13 & 6 & 28 & 10 & 4 & 22 \\
\hline $\mathrm{DBil}, \mu \mathrm{mol} / \mathrm{L}$ & 4.1 & 2.1 & 8.3 & 4.5 & 2.4 & 8.9 & 3.7 & 2.0 & 7.5 \\
\hline $\mathrm{ALT}, \mathrm{U} / \mathrm{L}$ & 15 & 7 & 38 & 19 & 9 & 42 & 13 & 6 & 31 \\
\hline $\mathrm{GGT}, \mathrm{U} / \mathrm{L}$ & 16 & 8 & 45 & 21 & 10 & 49 & 13 & 7 & 37 \\
\hline $\mathrm{ALP}, \mathrm{U} / \mathrm{L}$ & 58 & 35 & 98 & 63 & 40 & 99 & 54 & 33 & 97 \\
\hline $\mathrm{AST}, \mathrm{U} / \mathrm{L}$ & 17 & 11 & 28 & 19 & 12 & 29 & 16 & 11 & 27 \\
\hline $\mathrm{LDH}, \mathrm{U} / \mathrm{L}$ & 162 & 121 & 219 & 166 & 126 & 220 & 158 & 119 & 217 \\
\hline $\mathrm{K}, \mathrm{mmol} / \mathrm{L}$ & 4.2 & 3.7 & 4.9 & 4.2 & 3.7 & 4.8 & 4.2 & 3.7 & 4.9 \\
\hline $\mathrm{Na}, \mathrm{mmol} / \mathrm{L}$ & 141 & 137 & 144 & 141 & 138 & 144 & 140 & 137 & 144 \\
\hline $\mathrm{Cl}, \mathrm{mmol} / \mathrm{L}$ & 102 & 98 & 106 & 102 & 97 & 106 & 102 & 98 & 106 \\
\hline $\mathrm{IP}, \mathrm{mmol} / \mathrm{L}$ & 1.15 & 0.87 & 1.44 & 1.11 & 0.84 & 1.40 & 1.19 & 0.92 & 1.46 \\
\hline $\mathrm{Ca}, \mathrm{mmol} / \mathrm{L}$ & 2.37 & 2.20 & 2.54 & 2.39 & 2.23 & 2.56 & 2.35 & 2.19 & 2.53 \\
\hline $\mathrm{Urea}, \mathrm{mol} / \mathrm{L}$ & 4.34 & 2.60 & 6.90 & 4.71 & 3.05 & 7.22 & 4.03 & 2.45 & 6.48 \\
\hline $\mathrm{Glu}, \mathrm{mmol} / \mathrm{L}$ & 5.0 & 4.3 & 6.0 & 5.1 & 4.3 & 6.1 & 5.0 & 4.3 & 5.9 \\
\hline $\mathrm{UA}, \mathrm{mol} / \mathrm{L}$ & 295 & 177 & 475 & 355 & 238 & 506 & 255 & 166 & 375 \\
\hline $\mathrm{Cr}, \mathrm{mol} / \mathrm{L}$ & 69 & 49 & 100 & 83 & 66 & 105 & 61 & 47 & 78 \\
\hline $\mathrm{TC}, \mathrm{mmol} / \mathrm{L}$ & 4.5 & 3.2 & 6.4 & 4.6 & 3.2 & 6.3 & 4.5 & 3.2 & 6.4 \\
\hline $\mathrm{TG}, \mathrm{mmol} / \mathrm{L}$ & 0.95 & 0.44 & 2.50 & 1.12 & 0.50 & 2.68 & 0.84 & 0.42 & 2.22 \\
\hline $\mathrm{HDL}-\mathrm{C}, \mathrm{mmol} / \mathrm{L}$ & 1.36 & 0.86 & 2.15 & 1.21 & 0.81 & 1.91 & 1.49 & 0.96 & 2.24 \\
\hline $\mathrm{LDL}-\mathrm{C}, \mathrm{mmol} / \mathrm{L}$ & 2.80 & 1.63 & 4.44 & 2.93 & 1.73 & 4.48 & 2.69 & 1.57 & 4.40 \\
\hline
\end{tabular}

LL: lower limit; UL: upper limit. 
Table IV Distribution of common biochemical analytes by age.

\begin{tabular}{|c|c|c|c|c|c|c|c|c|c|c|c|c|c|c|c|}
\hline Analyte & 19 & 29 ye & & 30 & 39 ye & & 40 & 49 yea & & 50 & 64 ye & & $\geq 6$ & 5 yea & \\
\hline & median & $\mathrm{LL}$ & UL & median & $\mathrm{LL}$ & UL & median & LL & UL & median & $\mathrm{LL}$ & UL & median & LL & UL \\
\hline $\mathrm{TP}, \mathrm{g} / \mathrm{L}$ & 74 & 67 & 81 & 73 & 66 & 80 & 72 & 65 & 79 & 72 & 65 & 79 & 72 & 64 & 80 \\
\hline TBil, $\mu \mathrm{mol} / \mathrm{L}$ & 11 & 5 & 27 & 11 & 5 & 26 & 10 & 5 & 25 & 10 & 5 & 24 & 11 & 5 & 25 \\
\hline $\mathrm{DBil}, \mu \mathrm{mol} / \mathrm{L}$ & 4.3 & 2.2 & 8.8 & 4.1 & 2.1 & 8.3 & 3.9 & 2.0 & 7.9 & 3.9 & 2.1 & 7.8 & 4.2 & 2.3 & 8.7 \\
\hline $\mathrm{ALT}, \mathrm{U} / \mathrm{L}$ & 14 & 6 & 39 & 15 & 7 & 39 & 16 & 7 & 38 & 17 & 9 & 37 & 15 & 8 & 33 \\
\hline GGT, U/L & 14 & 7 & 39 & 15 & 8 & 44 & 16 & 8 & 47 & 18 & 9 & 47 & 17 & 9 & 43 \\
\hline ALP, U/L & 57 & 34 & 95 & 57 & 34 & 96 & 57 & 35 & 94 & 66 & 40 & 106 & 67 & 40 & 109 \\
\hline AST, U/L & 17 & 11 & 27 & 17 & 11 & 28 & 17 & 12 & 28 & 19 & 13 & 30 & 20 & 13 & 30 \\
\hline $\mathrm{LDH}, \mathrm{U} / \mathrm{L}$ & 159 & 121 & 213 & 158 & 120 & 212 & 162 & 121 & 216 & 173 & 130 & 232 & 182 & 136 & 251 \\
\hline $\mathrm{K}, \mathrm{mmol} / \mathrm{L}$ & 4.2 & 3.7 & 4.9 & 4.2 & 3.7 & 4.8 & 4.2 & 3.7 & 4.8 & 4.2 & 3.7 & 4.9 & 4.3 & 3.7 & 4.9 \\
\hline $\mathrm{Na}, \mathrm{mmol} / \mathrm{L}$ & 140 & 137 & 144 & 140 & 137 & 144 & 140 & 137 & 144 & 141 & 138 & 145 & 142 & 138 & 145 \\
\hline $\mathrm{Cl}, \mathrm{mmol} / \mathrm{L}$ & 102 & 97 & 106 & 102 & 98 & 106 & 102 & 98 & 106 & 103 & 98 & 107 & 103 & 98 & 107 \\
\hline $\mathrm{IP}, \mathrm{mmol} / \mathrm{L}$ & 1.21 & 0.93 & 1.48 & 1.15 & 0.88 & 1.43 & 1.12 & 0.86 & 1.40 & 1.15 & 0.85 & 1.44 & 1.10 & 0.83 & 1.40 \\
\hline $\mathrm{Ca}, \mathrm{mmol} / \mathrm{L}$ & 2.40 & 2.24 & 2.57 & 2.37 & 2.20 & 2.54 & 2.34 & 2.18 & 2.52 & 2.36 & 2.20 & 2.54 & 2.35 & 2.19 & 2.54 \\
\hline Urea, mol/L & 4.18 & 2.50 & 6.67 & 4.23 & 2.56 & 6.64 & 4.36 & 2.62 & 6.93 & 4.71 & 2.92 & 7.33 & 5.11 & 3.18 & 8.21 \\
\hline Glu, $\mathrm{mmol} / \mathrm{L}$ & 4.9 & 4.2 & 5.7 & 5.0 & 4.3 & 5.8 & 5.1 & 4.3 & 6.0 & 5.2 & 4.4 & 6.3 & 5.3 & 4.5 & 6.3 \\
\hline $\mathrm{UA}, \mu \mathrm{mol} / \mathrm{L}$ & 303 & 185 & 484 & 295 & 177 & 479 & 285 & 168 & 467 & 296 & 183 & 460 & 305 & 190 & 483 \\
\hline $\mathrm{Cr}, \mu \mathrm{mol} / \mathrm{L}$ & 70 & 49 & 101 & 69 & 48 & 100 & 69 & 48 & 100 & 70 & 49 & 100 & 75 & 51 & 108 \\
\hline $\mathrm{TC}, \mathrm{mmol} / \mathrm{L}$ & 4.25 & 3.07 & 5.91 & 4.42 & 3.16 & 6.12 & 4.65 & 3.30 & 6.36 & 5.00 & 3.46 & 6.84 & 4.95 & 3.25 & 6.86 \\
\hline $\mathrm{TG}, \mathrm{mmol} / \mathrm{L}$ & 0.80 & 0.41 & 2.09 & 0.91 & 0.44 & 2.45 & 1.02 & 0.47 & 2.59 & 1.18 & 0.54 & 2.68 & 1.19 & 0.56 & 2.65 \\
\hline $\mathrm{HDL}-\mathrm{C}, \mathrm{mmol} / \mathrm{L}$ & 1.40 & 0.88 & 2.15 & 1.34 & 0.85 & 2.12 & 1.35 & 0.85 & 2.14 & 1.35 & 0.85 & 2.20 & 1.37 & 0.84 & 2.26 \\
\hline $\mathrm{LDL}-\mathrm{C}, \mathrm{mmol} / \mathrm{L}$ & 2.52 & 1.51 & 4.04 & 2.72 & 1.60 & 4.28 & 2.92 & 1.75 & 4.47 & 3.21 & 1.92 & 4.82 & 3.14 & 1.67 & 4.77 \\
\hline
\end{tabular}

LL: lower limit; UL: upper limit.

\section{Discussion}

Common biochemical analytes are very important for evaluating the health condition of individuals, and reliable RIs are needed for physicians to interpret test results and diagnoses. Many clinical laboratories directly use RIs from foreign manufacturers or those found in the scientific literature; however, many factors including different ethnicity, analyzers, gender, and age can affect the distribution of biochemical analytes (14). Therefore, it is important to identify fully normal individual records and establish $\mathrm{Rls}$ for common biochemical analytes. Accordingly, an indirect sampling method and nonparametric analysis were applied to establish RIs for common biochemical analytes in this study.

As suggested by the results of MRA, gender was the major SV for 13 common biochemical analytes, whereas age was an important SV for 11 analytes. We found that gender-specific RIs should be established for ALT and AST, which have narrow RIs according to reported guidelines (18-23). ALP levels were sharply increased in patients greater than 50 years old, which is consistent with the results of a previous study (1723). In this study, we found that serum GGT levels in males were higher than those in females. A nationwide Chinese population-based cross-sectional study revealed that men had a higher serum level of GGT than women in each quartile (27). The RIs of GGT in this study were 10-49 U/L (male) and 7-37 U/L (female), which are narrower than the range for WS/T (10-60 U/L (male), 7-45 U/L (female)) (1823). A nationwide multicenter study in China reported that the RIs of GGT were 11-65 U/L (male) and 8$36 \mathrm{U} / \mathrm{L}$ (female) (17). Thus, we recommend establishing gender-specific RIs for GGT ( $\left.r_{p}=-0.330\right)$. This study revealed that age- or gender-specific RIs are unnecessary for $\mathrm{K}, \mathrm{Na}, \mathrm{Cl}, \mathrm{Ca}$, and IP, as no clinically significant differences were observed, which is consistent with the results of previous studies (1723). Based on the results described above, the RIs of common biochemical analytes were established in this study, most of which were significantly narrower than those listed in the WS/T 404 (18-23). Additionally, the ranges of TP, ALT, GGT, ALP, AST, K, $\mathrm{Na}, \mathrm{Cl}$, and IP in this study were significantly lower, while the distributions of TBil, and $\mathrm{Ca}$ were higher than those in the WS/T 404.

There were several advantages in this study. Firstly, few studies have established RIs for common biochemical analytes using the indirect sampling method $(13,29)$. Use of the direct sampling method requires the recruitment of healthy individuals rather 
Supplemental Table I Comparation reference interval of common biochemical analytes between this study and WS/T 404 .

\begin{tabular}{|c|c|c|c|c|}
\hline Analyte & Unit & Sex & Age & Reference interval \\
\hline \multirow[t]{4}{*}{ Urea } & $\mathrm{mmol} / \mathrm{L}$ & Male & $20-59$ & $3.1-8.0$ \\
\hline & $\mathrm{mmol} / \mathrm{L}$ & Male & $60-79$ & $3.9-9.5$ \\
\hline & $\mathrm{mmol} / \mathrm{L}$ & Female & $20-59$ & $2.6-7.5$ \\
\hline & $\mathrm{mmol} / \mathrm{L}$ & Female & $60-79$ & $3.1-8.8$ \\
\hline \multirow[t]{4}{*}{$\mathrm{Cr}$} & $\mu \mathrm{mol} / \mathrm{L}$ & Male & $20-59$ & 57-97 \\
\hline & $\mu \mathrm{mol} / \mathrm{L}$ & Male & $60-79$ & $57-111$ \\
\hline & $\mu \mathrm{mol} / \mathrm{L}$ & Female & $20-59$ & $41-73$ \\
\hline & $\mu \mathrm{mol} / \mathrm{L}$ & Female & $60-79$ & $41-81$ \\
\hline $\mathrm{Ca}$ & $\mathrm{mmol} / \mathrm{L}$ & Total & None & $2.11-2.52$ \\
\hline IP & $\mathrm{mmol} / \mathrm{L}$ & Total & None & $0.85-1.51$ \\
\hline $\mathrm{Mg}$ & $\mathrm{mmol} / \mathrm{L}$ & Total & None & $0.75-1.02$ \\
\hline LD & $U / L$ & Total & None & $120-250$ \\
\hline \multirow[t]{2}{*}{$\mathrm{CK}$} & $U / L$ & Male & None & $50-310$ \\
\hline & $U / L$ & Female & None & $40-200$ \\
\hline AMY & $U / L$ & Total & None & $35-135$ \\
\hline TP & $\mathrm{g} / \mathrm{L}$ & Total & None & $65-85$ \\
\hline Alb & $\mathrm{g} / \mathrm{L}$ & Total & None & $40-55$ \\
\hline GLB & $g / L$ & Total & None & $20-40$ \\
\hline $\mathrm{K}$ & $\mathrm{mmol} / \mathrm{L}$ & Total & None & $3.5-5.3$ \\
\hline $\mathrm{Na}$ & $\mathrm{mmol} / \mathrm{L}$ & Total & None & $137-147$ \\
\hline $\mathrm{Cl}$ & $\mathrm{mmol} / \mathrm{L}$ & Total & None & $99-110$ \\
\hline \multirow[t]{3}{*}{ TBil } & $\mu \mathrm{mol} / \mathrm{L}$ & Male & None & $\leq 26$ \\
\hline & $\mu \mathrm{mol} / \mathrm{L}$ & Female & None & $\leq 21$ \\
\hline & $\mu \mathrm{mol} / \mathrm{L}$ & Total & None & $\leq 23$ \\
\hline DBIL & $\mu \mathrm{mol} / \mathrm{L}$ & Total & None & $\leq 8$ \\
\hline \multirow[t]{2}{*}{$\mathrm{ALT}$} & $U / L$ & Male & None & $9-50$ \\
\hline & $U / L$ & Female & None & $7-40$ \\
\hline \multirow[t]{2}{*}{$\begin{array}{c}\text { ALT (with 5' } \\
\text { pyridoxal phosphate) }\end{array}$} & $U / L$ & Male & None & $9-60$ \\
\hline & $U / L$ & Female & None & $7-45$ \\
\hline \multirow[t]{2}{*}{ AST } & $U / L$ & Male & None & $15-40$ \\
\hline & $U / L$ & Female & None & $13-35$ \\
\hline \multirow[t]{2}{*}{ AST (with 5 pyridoxal phos- } & $U / L$ & Male & None & $15-45$ \\
\hline & $\mathrm{U} / \mathrm{L}$ & Female & None & $13-40$ \\
\hline \multirow[t]{3}{*}{ ALP } & $U / L$ & Male & None & $45-125$ \\
\hline & $U / L$ & Female & $20-49$ & $35-100$ \\
\hline & $U / L$ & Female & $50-79$ & $50-135$ \\
\hline \multirow[t]{2}{*}{ GGT } & $U / L$ & Male & None & $10-60$ \\
\hline & $\mathrm{U} / \mathrm{L}$ & Female & None & $7-45$ \\
\hline
\end{tabular}


than directly collecting big clinical data, which is timeconsuming and costly (30). In contrast, using an indirect sampling method is much easier and more costefficient. We also included a large cohort of patients for whom health checkups were performed for five years at the same facility to reduce inter-assay variation. Otherwise, all measurements were performed according to our laboratory standard operating procedures. Our laboratory also takes part in external quality assessments by the National Center for Clinical Laboratories and the College of American Pathologists to guarantee the accuracy and reliability of our study (9).

In this study, we identified the main SVs contributing to the distribution of common biochemical analytes using the MRA method and established ageor gender-specific Rls using an indirect sampling

\section{References}

1. Gräsbeck R, Fellman J. Normal values and statistics. Scand J Clin Lab Invest 1968; 21(3): 193-5.

2. Ichihara K, Ozarda Y, Barth JH, Klee G, Qiu L, Erasmus $R$, et al. A global multicenter study on reference values: 1. Assessment of methods for derivation and comparison of reference intervals. Clin Chim Acta 2017, 467: 7082.

3. Mu R, Yun K, Yu X, Cheng S, Ma M, Zhang X, et al. A study on reference interval transference via linear regression. Clin Chem Lab Med 2019 [Epub ahead of print].

4. Ceriotti F, Henny J, Queralto J, Ziyu S, Ozarda Y, Chen B, et al. Common reference intervals for aspartate aminotransferase (AST), alanine aminotransferase (ALT) and gamma-glutamyl transferase (GGT) in serum: results from an IFCC multicenter study. Clin Chem Lab Med 2010; 48(11): 1593-601.

5. Thienpont LM, Van Uytfanghe K, De Grande LAC, Reynders D, Das B, Faix JD, et al. Harmonization of serum thyroid-stimulating hormone measurements Ppaves the way for the adoption of a more uniform reference interval. Clin Chem 2017; 63(7): 1248-60.

6. Ichihara K, Ozarda Y, Klee G, Straseski J, Baumann N, Ishikura K. Utility of a panel of sera for the alignment of test results in the worldwide multicenter study on reference values. Clin Chem Lab Med 2013; 51(5): 100725.

7. Wang D, Yu S, Ma C, Li H, Qiu L, Cheng X, et al. Reference intervals for thyroid-stimulating hormone, free thyroxine, and free triiodothyronine in elderly Chinese persons. Clin Chem Lab Med 2019; 57(7): 1044-52.

8. Wang D, Li D, Guo X, Yu S, Qiu L, Cheng X, et al. Effects of sex, age, sampling time, and season on thyroid-stimulating hormone concentrations: A retrospective study. Biochem Biophys Res Commun 2018; 506(3): 450-54.

9. Wang D, Cheng X, Yu S, Qiu L, Lian X, Guo X, et al. Data mining: Seasonal and temperature fluctuations in method. We recommend that gender-specific RIs should be established for ALT, AST, GGT, DBil, TBil, UA, and $\mathrm{Cr}$, as well as gender- and age-specific RIs for urea and ALP. Using an indirect sampling method may enable more laboratories to establish their own RIs, particularly for specific populations such as the elderly and children. Guidelines for determining standard Rls based on big clinical data are needed.

Acknowledgements. This work was funded by research grants from the National Natural Science Foundation of China (grant number 81702060) (http://www.nsfc.gov.cn/).

\section{Conflict of interest statement}

The authors state that they have no conflicts of interest regarding the publication of this article.

thyroid-stimulating hormone. Clin Biochem 2018; 60: 59-63.

10. Li D, Wang D, Wang D, Ma C, Wu J, Li P, et al. Data mining: Biological and temporal factors associated with blood cardiac troponin I concentration in a Chinese population. Clin Chim Acta 2019; 495: 8-12.

11. Solberg HE. International Federation of Clinical Chemistry. Scientific committee, Clinical Section. Expert Panel on Theory of Reference Values and International Committee for Standardization in Haematology Standing Committee on Reference Values. Approved recommendation (1986) on the theory of reference values. Part 1. The concept of reference values. Clin Chim Acta 1987; 165(1): 111-8.

12. CLSI, C.A.L.S. Defining, establishing, and verifying reference intervals in the clinical laboratory; approved guideline. Defining, establishing, and verifying reference intervals in the clinical laboratory; approved guideline third edition. Third edition. CLSI document C28-A3. 201.

13. Shaw JL, Cohen A, Konforte D, Binesh-Marvasti T, Colantonio DA, Adeli K. Validity of establishing pediatric reference intervals based on hospital patient data: a comparison of the modified Hoffmann approach to CALIPER reference intervals obtained in healthy children. Clin Biochem 2014; 47(3): 166-72.

14. Shah SAV, Ichihara K, Dherai AJ, Ashavaid TF. Reference intervals for 33 biochemical analytes in healthy Indian population: C-RIDL IFCC initiative. Clin Chem Lab Med 2018; 56(12): 2093-103.

15. Hoffmann RG. Statistics in the practice of medicine. JAMA 1963; 14(185): 864-73.

16. Lykkeboe S, Nielsen CG, Christensen PA. Indirect method for validating transference of reference intervals. Clin Chem Lab Med 2018; 56(3): 463-70.

17. Xia L, Chen M, Liu M. Nationwide Multicenter Reference Interval Study for 28 Common Biochemical Analytes in China. Medicine (Baltimore). 2016 Mar; 95(9): e2915. 
18. Ministry of Health PRC. Reference interval for common clinical biochemistry tests - Part 1: Serum alanin aminotransferase, aspartate aminotransferase, alkaline phosphatase and gama-glutamyltransferase. WS/T 404.12012.

19. Ministry of Health PRC. Reference interval for common clinical biochemistry tests - Part 2: Serum total protein and albumin. WS/T 404.2-2012.

20. Ministry of Health PRC. Reference interval for common clinical biochemistry tests - Part 3: Serum potassium, sodium and chloride. WS/T 404.3-2012.

21. Ministry of Health PRC. Reference interval for common clinical biochemistry tests - Part 4: Serum Total bilirubin and Direct bilirubin. WS/T 404.5-2018.

22. Ministry of Health PRC. Reference interval for common clinical biochemistry tests - Part 5: Serum urea and creatinine. WS/T 404.5-2015.

23. Ministry of Health PRC. Reference interval for common clinical biochemistry tests - Part 6: Serum calcium, phosphorus, magnesium. Iron. WS/T 404.6-2015.

24. Ministry of Health PRC. Reference interval for common clinical biochemistry tests - Part 7: Serum lactate dehydrogenase, creatine. WS/T 404.7-2015.

25. Yamakado M, Ichihara K, Matsumoto $Y$, Ishikawa $Y$, Kato $K$, Komatsubara $Y$, et al. Derivation of gender and age- specific reference intervals from fully normal Japanese individuals and the implications for health screening. Clin Chem Acta 2015; 447: 105-14.

26. Wang D, Yu S, Cheng X, Cao L, Zhang H, Liu L, et al. Nationwide Chinese study for establishing reference intervals for thyroid hormones and related tests. Clin Chem Acta 2019; 496: 62-7.

27. Yu S, Wang D, Yin Y, Cheng Q, Xie S, Yu J, et al. Sources of variation evaluation of $24,25(\mathrm{OH}) 2 \mathrm{D}$ levels and the ratio of $25 \mathrm{OHD}$ to $24,25(\mathrm{OH}) 2 \mathrm{D}$ in apparently healthy Chinese adults: a multicenter cross-sectional study. J Steroid Biochem 2019; 192: 105407.

28. Li DD, Xu T, Cheng X, et al. Serum Gamma-Glutamyltransferase Levels are Associated with Cardiovascular Risk Factors in China: A Nationwide Population Based Study. Sci Rep 2018 Nov 8; 8(1): 16533.

29. Hoq M, Karlaftis V, Mathews S, Burgess J, Donath SM, Carlin J, et al. A prospective, cross-sectional study to establish age-specific reference intervals for neonates and children in the setting of clinical biochemistry, immunology and haematology: the HAPPI Kids study protocol. BMJ Open 2019; 9(4): e025897.

30. Koerbin G, Cavanaugh JA, Potter JM, Abhayaratna WP, West NP, Glasgow N, et al. 'Aussie normals': an a priori study to develop clinical chemistry reference intervals in a healthy Australian population. Pathology 2015; 47(2): 138-44. 